\title{
Frondihabitans cladoniiphilus sp. nov., an actinobacterium of the family Microbacteriaceae isolated from lichen, and emended description of the genus Frondihabitans
}

Correspondence Massimiliano Cardinale m.cardinale@tugraz.at

\author{
Massimiliano Cardinale, ${ }^{1}$ Martin Grube $^{2}$ and Gabriele Berg ${ }^{1}$ \\ ${ }^{1}$ Institute of Environmental Biotechnology, Graz University of Technology, Petersgasse 12, \\ A-8010 Graz, Austria \\ ${ }^{2}$ Institute of Plant Science, Karl-Franzens University Graz, Holteigasse 6, A-8010 Graz, Austria
}

Bacterial communities associated with lichens were recently characterized based on cultivation-dependent and cultivation-independent methods (Grube \& Berg, 2009). These communities are species-specific and include members of many bacterial phyla (Grube et al., 2009; Schneider et al., 2011). Alphaproteobacteria constitute the most abundant group, as detected by specific in situ hybridization, followed by Betaproteobacteria, Gammaproteobacteria, Deltaproteobacteria, Actinobacteria and Firmicutes (Cardinale et al., 2008; Hodkinson \& Lutzoni, 2009). The occurrence of other bacterial groups and Archaea was also shown (Bjelland et al., 2011; Selbmann et al., 2010; Bates et al., 2011; J. Vieira de Castro and others, unpublished). During a comparative study of bacterial diversity in different thallus parts of the reindeer lichen Cladonia arbuscula (Wallr.) Rabenh., we isolated two actinobacteria (strains $\mathrm{CafT}_{13}{ }^{\mathrm{T}}$ and CafM5) from the juvenile part of a healthy thallus that was growing in the

Abbreviation: ISP, International Streptomyces Project.

The GenBank/EMBL/DDBJ accession number for the 16S rRNA gene sequence of strain $\mathrm{CafT}_{13}{ }^{\top}$ is FN666417. understorey of a natural spruce forest. The 16S rRNA gene sequences of the two strains were identical (100\% similarity) and indicated placement in the family Microbacteriaceae; CafT $13^{\mathrm{T}}$ was chosen as a representative strain and characterized further. Highest levels of $16 \mathrm{~S}$ rRNA gene sequence similarity were found between strain $\mathrm{CafT} 13^{\mathrm{T}}$ and the type strains of Frondihabitans peucedani and Frondihabitans australicus (97.2 and $97.1 \%$, respectively). Strain CafT13 ${ }^{\mathrm{T}}$ was also shown to be closely related to members of the genera Subtercola, Frigoribacterium and Curtobacterium (highest levels of 16S rRNA gene sequence similarity of $96.2,96.2$ and $95.5 \%$, respectively).

We used a polyphasic approach to further characterize strain $\mathrm{CafT} 13^{\mathrm{T}}$ in accordance with the standard guidelines for the suborder Micrococcineae (Schumann et al., 2009).

Phylogenetic analysis demonstrated that strain $\mathrm{CafT} 3^{\mathrm{T}}$ is separate from recognized species of the genera Frondihabitans, Frigoribacterium, Curtobacterium and Subtercola. Based on phenotypic, physiological and chemotaxonomic differences as well as phylogenetic distance from its closest 
relatives, we propose that strain $\mathrm{CafT}_{1} 3^{\mathrm{T}}$ represents a novel species of the genus Frondihabitans in the family Microbacteriaceae (following standard nomenclature rules; Tindall et al., 2006).

Strain CafT $13^{\mathrm{T}}$ has been conserved at $-70{ }^{\circ} \mathrm{C}$ in the Strain Collection of Antagonistic Micro-organisms (SCAM) at the Institute of Environmental Biotechnology, Graz University of Technology (TU-Graz), and in the DSMZ and BCCM/ LMG public culture collections.

A thallus of the lichen Cladonia arbuscula was collected, by wearing gloves and by using sterilized, ethanol-cleaned forceps, under a natural spruce forest at Koralpe, in the Austrian Alps at the border between Styria and Carinthia (Handalm: $46^{\circ} 50^{\prime} 35^{\prime \prime} \mathrm{N} 15^{\circ} 01^{\prime} 20^{\prime \prime} \mathrm{E}$, about $1780 \mathrm{~m}$ above sea-level). The sample was placed in a sterile $50 \mathrm{ml}$ screw-capped tube and stored in a refrigerated bag. After about $6 \mathrm{~h}$, the sample was processed for bacterial isolation. The thallus was crushed in $0.8 \% \mathrm{NaCl}$ solution and serial diluents of the suspension were plated onto tryptone-yeast extract medium (Carl Roth). After 6 days of incubation at $20{ }^{\circ} \mathrm{C}$, two yellowish-pigmented colonies were picked, streaked onto fresh plates and designated $\mathrm{CafT}_{1}{ }^{\mathrm{T}}$ and CafM5. Growth was tested on several media and the best results were achieved with International Streptomyces Project (ISP) medium 2 (Shirling \& Gottlieb, 1966). A considerable amount of extracellular matrix was produced by strain $\mathrm{CafT}_{1} 3^{\mathrm{T}}$ on this medium, especially when grown below $10{ }^{\circ} \mathrm{C}$; the colonies appeared yellowish, turning to bright yellow after 4-5 days of growth. Growth in liquid culture was performed at $24{ }^{\circ} \mathrm{C}$ with shaking at 220 r.p.m., and was characterized by the formation of a mucous and filamentous cell aggregate sticking to the bottom of the tube, this aggregate being relatively difficult to disaggregate or resuspend. The $\mathrm{pH}$ range for growth was established in liquid cultures; a pre-inoculum was grown in ISP 2 at $24{ }^{\circ} \mathrm{C}$ for $30 \mathrm{~h}$, and $350 \mu$ labout $5 \times 10^{6}$ cells) was then added to $50 \mathrm{ml}$ filter-sterilized ISP 2 with $\mathrm{pH}$ values adjusted to 3-12 (single $\mathrm{pH}$ unit intervals). The flasks were incubated with shaking at 150 r.p.m. for $70 \mathrm{~h}$ and the $\mathrm{OD}_{600}$ was then measured with a spectrophotometer. Growth occurred at (initial) $\mathrm{pH} 3-8$, optimally at $\mathrm{pH} 4-7$. Growth was very poor at $\mathrm{pH} 3$ and was absent at $\mathrm{pH} 9-12$. $\mathrm{pH}$ was also measured after bacterial growth; acidification of the medium at initial $\mathrm{pH} 6,7$ and 8 was detected $(\mathrm{pH} 4.58$, 4.91 and 5.02, respectively, after growth), whereas at initial $\mathrm{pH} 4$ and 5 there was only a slight acidification ( $\mathrm{pH} 3.73$ and 4.76 , respectively). The experiments were repeated at $\mathrm{pH}$ 3-9 by using a buffering system consisting of $0.05 \mathrm{M}$ $\mathrm{NaH}_{2} \mathrm{PO}_{4} / \mathrm{Na}_{2} \mathrm{HPO}_{4}$ (Miller et al., 2005) to define exactly the optimal $\mathrm{pH}$ range for growth. Growth was confirmed to occur at the initial $\mathrm{pH}$ values given above; after bacterial growth, acidification of the medium was again noted (values of $\mathrm{pH}$ before/after bacterial growth: 4/3.72, 5/4.36, 6/5.31 and 7/5.34). We concluded that strain $\mathrm{CafT}_{13}{ }^{\mathrm{T}}$ is an acidophilic bacterium, showing optimal growth at pH 3.7-5.4.
The temperature range for growth was established on the basis of growth on solid medium. ISP 2 plates were streaked with strain CafT $13^{\mathrm{T}}$, incubated at 1, 4, 15, 20, 22, 24, 26, 30 and $37^{\circ} \mathrm{C}$ and monitored for 14 days. Growth was observed at $1-30{ }^{\circ} \mathrm{C}$, with optimum growth at $22-26{ }^{\circ} \mathrm{C}$.

Motility and oxygen relationships were tested in ISP 2 plus $0.3 \%$ agar-agar (Roth) by using transparent inoculation tubes. A few identical colonies were harvested from a plate with a sterile needle and inoculated through the centre of the medium to approximately one-half the depth of the medium (Tittsler \& Sandholzer, 1936). Growth behaviour was observed during 3 weeks of incubation at both 22 and $30{ }^{\circ} \mathrm{C}$ in the dark and in vertical inoculation tubes, demonstrating that cells of strain $\mathrm{CafT}^{\mathrm{T}} 3^{\mathrm{T}}$ are strictly aerobic and non-motile.

For API tests, strain CafT $13^{\mathrm{T}}$ and the type strains of $F$. australicus and F. peucedani were grown on ISP 2 at $24{ }^{\circ} \mathrm{C}$ for 3 days, and all tests were performed as recommended by the manufacturer (bioMérieux). API ZYM tests were performed after incubation at $26{ }^{\circ} \mathrm{C}$ for $20 \mathrm{~h}$. Strain $\mathrm{CafT} 3^{\mathrm{T}}$ was positive for alkaline phosphatase, esterase (C4), esterase lipase (C8), lipase (C14), leucine arylamidase, cystine arylamidase, trypsin, $\alpha$-chymotrypsin, acid phosphatase, naphthol-AS-BI-phosphohydrolase, $\alpha$-galactosidase, $\beta$-galactosidase, $\alpha$-glucosidase, $\beta$-glucosidase, $N$ acetyl- $\beta$-glucosaminidase and $\alpha$-mannosidase, but negative for valine arylamidase, $\beta$-glucuronidase and $\beta$-fucosidase. API Coryne tests were performed after incubation at $26{ }^{\circ} \mathrm{C}$ for $45 \mathrm{~h}$. Strain $\mathrm{CafT}_{13^{\mathrm{T}}}$ was positive for pyrrolidonyl arylamidase and gelatin hydrolysis, but negative for nitrate reduction, pyrazinamidase, urease, and fermentation of glucose, ribose, xylose, mannitol, maltose, lactose, sucrose and glycogen. Catalase activity (21st test of the API Coryne strip) was positive. API 20NE tests were performed after incubation at $26{ }^{\circ} \mathrm{C}$ for $45 \mathrm{~h}$. Strain $\mathrm{CafT} 13^{\mathrm{T}}$ was positive for $\beta$-glucosidase (aesculin degradation) and assimilation of $N$-acetyl-D-glucosamine, but negative for indole production, arginine dihydrolase, and assimilation of Dglucose, L-arabinose, D-mannose, D-mannitol, maltose, potassium gluconate, capric acid, adipic acid, malic acid, trisodium citrate and phenylacetic acid. The cytochrome oxidase test, determined with oxidase detection strips (bioMérieux), was negative. The API tests results showed remarkable differences between the enzyme spectrum of strain $\mathrm{CafT}_{1} 3^{\mathrm{T}}$ and those of the type strains of F. australicus and F. peucedani, with 17 differences out of 49 tested reactions (Table 1 ).

Morphology and colour of the colonies were checked with a stereomicroscope after 5 days of growth on ISP 2 at $24{ }^{\circ} \mathrm{C}$. Single colonies were $\sim 1 \mathrm{~mm}$ in diameter, bright yellow, slightly translucent, circular, raised-to-convex and with entire margins. When grown at $<10{ }^{\circ} \mathrm{C}$, single colonies appeared punctiform.

Cell morphology was determined by bright-field and differential interference contrast microscopy. Cells of strain $\mathrm{CafT}^{\mathrm{T}} 3^{\mathrm{T}}$ were non-flagellated, non-sporulating short rods, 
Table 1. Differential characteristics of strain $\mathrm{CafT}_{1} 3^{\top}$ and the type strains of recognized Frondihabitans species

Strains: 1 , CafT13 ${ }^{\mathrm{T}} ; 2$, F. australicus E1HC- $02^{\mathrm{T}} ; 3$, F. peucedani RS- $15^{\mathrm{T}}$. ND, Not determined.

\begin{tabular}{|c|c|c|c|}
\hline Characteristic & 1 & 2 & 3 \\
\hline Colony colour & Yellow & White & Yellow \\
\hline Cellular arrangement & Aggregates & Single cells & Single cells \\
\hline Range & $1-30$ & $15-37$ & $4-37$ \\
\hline Optimum & $22-26$ & 30 & $20-30$ \\
\hline \multicolumn{4}{|l|}{ Growth pH } \\
\hline Optimum & $3.7-5.4$ & 9.1 & $8.1-11.1$ \\
\hline $\begin{array}{l}\text { DNA G }+C \text { content }(\mathrm{mol} \% \\
\text { mean } \pm \text { SD })\end{array}$ & $69.0 \pm 0.17$ & $71 \pm 1$ & 68.3 \\
\hline Major fatty acids (\%) & $\begin{array}{c}\mathrm{C}_{18: 1}(79.3), \mathrm{C}_{14: 0} 2-\mathrm{OH}(7.22) \\
\mathrm{C}_{17: 1} \omega 9 c(3.2), \mathrm{C}_{16: 0}(2.7) \\
\text { anteiso- } \mathrm{C}_{15: 0}(2.4)\end{array}$ & $\begin{array}{c}\mathrm{C}_{18: 1} \omega 7 c(70.0-71.1), \mathrm{C}_{14: 0} \\
2-\mathrm{OH}(6.5-9.7)\end{array}$ & $\begin{array}{c}\mathrm{C}_{18: 1} \omega 7 c(31.5-35.0) \\
\text { anteiso- } \mathrm{C}_{15: 0}(28.4-30.9) \\
\mathrm{C}_{14: 0} 2-\mathrm{OH}(16.7-18.4)\end{array}$ \\
\hline Valine arylamidase & - & + & - \\
\hline Cystine arylamidase & + & + & - \\
\hline Trypsin & + & + & - \\
\hline$\alpha$-Chymotrypsin & + & + & - \\
\hline$\alpha$-Galactosidase & + & + & - \\
\hline$\alpha$-Mannosidase & + & + & - \\
\hline$\alpha$-Fucosidase & - & + & - \\
\hline Gelatin hydrolysis & + & - & - \\
\hline \multicolumn{4}{|l|}{ Assimilation of: } \\
\hline D-Glucose & - & + & - \\
\hline D-Mannose & - & + & - \\
\hline
\end{tabular}

typically curved in the middle and with clubbed ends (Fig. 1a). Cell size was $1.2-2.0 \times 0.5-0.9 \mu \mathrm{m}$. The rod-coccoid life cycle was not detected. Clusters of a few to about a thousand cells were often observed in samples collected from both liquid and solid cultures (Fig. 1b). This tendency to form aggregates might explain the occurrence of floccules in liquid culture. Interestingly, Bright \& Bulgheresi (2010) showed that auto-aggregation is often a prerequisite of host attachment and therefore it is a characteristic related to a symbiotic lifestyle (e.g. for Sinorhizobium meliloti).

For DNA extraction, cell pellets collected from the plate were treated with $10 \mathrm{mg}$ lysozyme $\mathrm{ml}^{-1}, 20 \mathrm{mg}$ proteinase $\mathrm{K} \mathrm{ml}^{-1}$ and $10 \%$ SDS; phenol/chloroform/isoamylalcohol at 25:24:1 was used to separate DNA from proteins and finally the DNA was precipitated with ice-cold ethanol, dried, resuspended in $10 \mathrm{mM}$ Tris/ $\mathrm{HCl}, \mathrm{pH} 7.5$, and stored at $-20{ }^{\circ} \mathrm{C}$. About $150-200 \mathrm{ng}$ DNA was used as a template for amplification of the 16S rRNA gene by PCR.
Primers Eub1/1492r (5'-AGAGTTTGATCCTGGCTCAG$3^{\prime} / 5^{\prime}$-GGYTACCTTGTTACGACTT-3') were added to the Taq-and-go kit (MP Biomedicals) and the following program was run: initial denaturation $\left(95{ }^{\circ} \mathrm{C}\right.$ for $\left.10 \mathrm{~min}\right)$ followed by 30 cycles of denaturation $\left(94{ }^{\circ} \mathrm{C}, 30 \mathrm{~s}\right)$, annealing $\left(52{ }^{\circ} \mathrm{C}, 30 \mathrm{~s}\right)$ and extension $\left(72{ }^{\circ} \mathrm{C}, 60 \mathrm{~s}\right)$, and a final extension $\left(72{ }^{\circ} \mathrm{C}, 5 \mathrm{~min}\right)$. Five microlitres of PCR product was checked by $1 \%$ agarose gel electrophoresis. The PCR product was purified, both strands were sequenced and the sequences were assembled with the software MEGA4 (Tamura et al., 2007). A final 16S rRNA gene sequence of $1390 \mathrm{nt}$ of strain $\mathrm{CafT} 13^{\mathrm{T}}$ was obtained and used for phylogenetic analysis.

The 16SrRNA gene sequence of strain CafT $13^{\mathrm{T}}$ was aligned with those of the type strains of the type species of each genus in the family Microbacteriaceae and with that of $F$. peucedani $\mathrm{RS}-15^{\mathrm{T}}$ (Lee, 2010), by using the program Clustal $\mathrm{X} 2$ (Larkin et al., 2007). The resulting multi-alignment was improved with the software MEGA4 by removing 

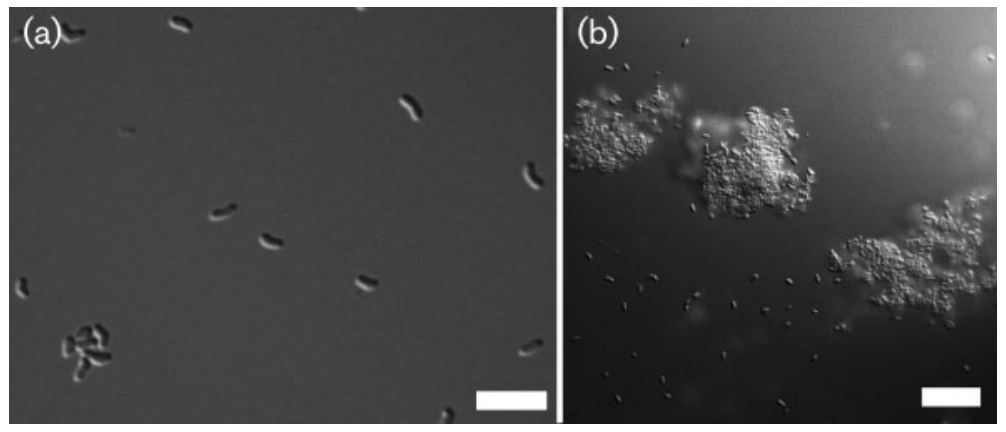

Fig. 1. Differential interference contrast micrographs showing the cell morphology of strain $\mathrm{CafT}_{13}{ }^{\top}$. Cells were grown in liquid ISP 2 at $24{ }^{\circ} \mathrm{C}$ and 150 r.p.m. and were observed with a $63 \times$ oil-immersion objective (numerical aperture 1.30; Leica Microsystems). (a) The typical coryneform shape, the clubbed ends and a small cluster of six cells are visible; bar, $5 \mu \mathrm{m}$. (b) Large auto-aggregated cell clusters were detected after $48 \mathrm{~h}$ of growth in liquid ISP 2; bar, $15 \mu \mathrm{m}$.

incomplete parts at both the beginning and the end of the sequence, and by manually changing the position of a few nucleotides, where necessary. The optimized multi-alignment comprised 1396 unambiguously aligned positions (including alignment gaps) and was used for phylogenetic analyses performed with the PHYLIP package version 6.69 (Felsenstein, 1989, 2005). The maximum-parsimony tree (Eck \& Dayhoff, 1966; Kluge \& Farris, 1969) was inferred directly from the aligned sequences. A distance matrix was obtained with the Jukes-Cantor model (Jukes \& Cantor, 1969) and used as input for both the neighbour-joining (Saitou \& Nei, 1987) and the minimum-evolution tree (Kidd \& Sgaramella-Zonta, 1971; Rzhetsky \& Nei, 1993). Bootstrap analysis based on 1000 replicates was applied to test for the confidence of tree topologies. The results showed that strain $\mathrm{CafT}_{13}{ }^{\mathrm{T}}$ formed a monophyletic branch together with recognized species of the genus
Frondihabitans (Fig. 2). The position of strain CafT $13^{\mathrm{T}}$ did not vary with the method of tree reconstruction used and it was supported by high bootstrap values (Fig. 2).

Cells of strain $\mathrm{CafT}^{\mathrm{T}}{ }^{\mathrm{T}}$ were disrupted with a French pressure cell and the DNA was purified by chromatography on hydroxyapatite according to Cashion et al. (1977).

For calculation of the $\mathrm{G}+\mathrm{C}$ content, DNA was hydrolysed with P1 nuclease and the nucleotides were dephosphorylated with bovine alkaline phosphatase (Mesbah et al., 1989). The resulting deoxyribonucleosides were analysed by HPLC. The HPLC system (Shimadzu) consisted of the following: an LC20AD solvent delivery module, DGU-3A online degasser, CTO-10AC column oven, SIL-20A automatic sample injector and SPD-6A UV spectrophotometric detector. Chromatograms were analysed by using the CLARITY software package (DataApex). The analytical column was a VYDAC 201SP54,

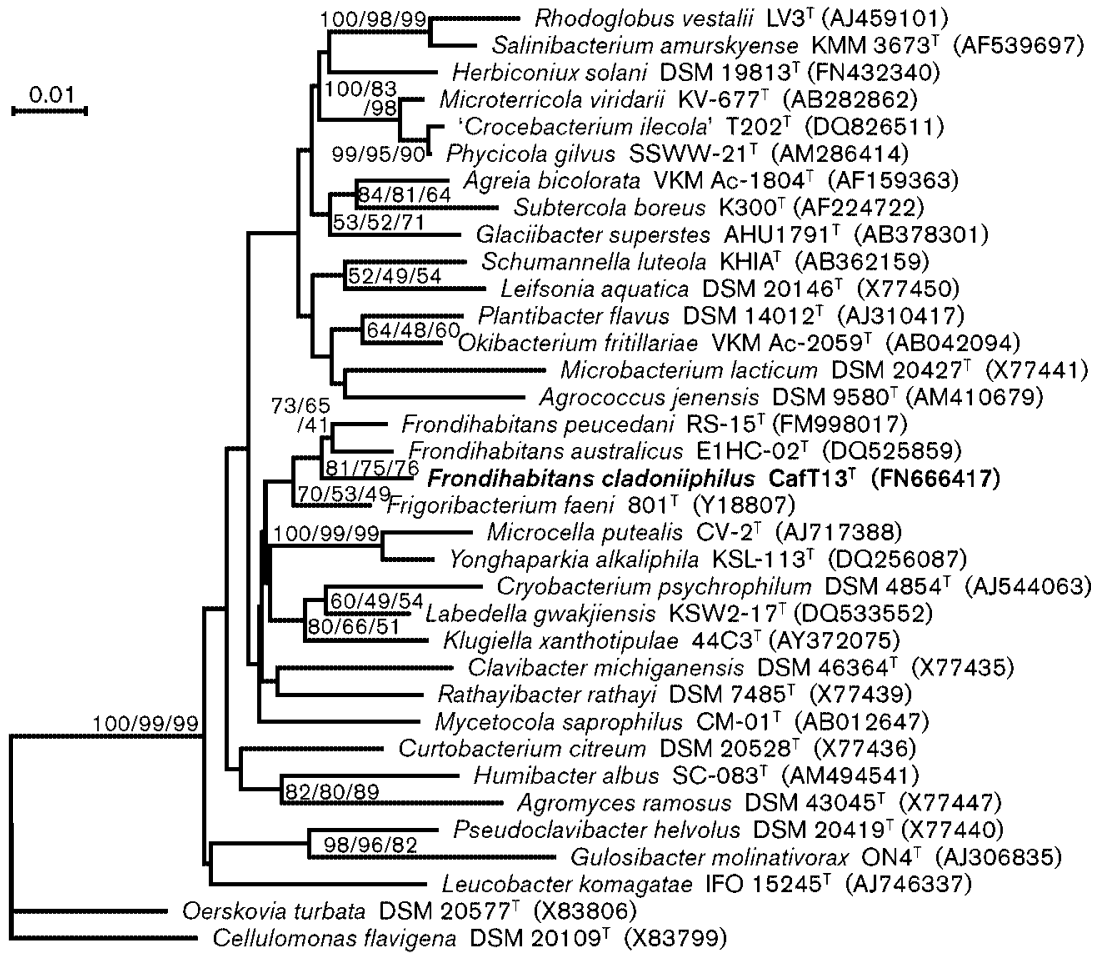

Fig. 2. Phylogenetic tree based on a multialignment of $1396 \mathrm{nt}$ of the 16S rRNA gene sequence showing the relationships between strain CafT $13^{\top}$ and the type strains of recognized Frondihabitans species and of the type species of all other genera in the family Microbacteriaceae. The tree topology was inferred by the neighbour-joining method. Numbers at nodes are bootstrap values as percentages of 1000 data resamplings, obtained by the neighbour-joining/minimum-evolution/maximum-parsimony methods, respectively; only values $\geqslant 50 \%$ (obtained by at least one method) are shown. Sequences of members of the Cellulomonadaceae were used as the outgroup. Bar, 0.01 substitutions per site. 
$\mathrm{C}_{18}, 5 \mu \mathrm{m}(250 \times 4.6 \mathrm{~mm})$ equipped with a $201 \mathrm{GD} 54 \mathrm{H}$ guard column (Vydac). The chromatography conditions were: $45{ }^{\circ} \mathrm{C}, 10 \mu \mathrm{l}$ sample, $0.3 \mathrm{M}\left(\mathrm{NH}_{4}\right) \mathrm{H}_{2} \mathrm{PO}_{4}$ /acetonitrile $(40: 1, \mathrm{v} / \mathrm{v})$ as solvent, $\mathrm{pH} 4.4,1.3 \mathrm{ml} \mathrm{min}{ }^{-1}$ (Tamaoka \& Komagata, 1984). As reference DNA we used: non-methylated Lambda-DNA (G+C content $49.858 \mathrm{~mol} \%$ ), Bacillus subtilis DSM 402 (43.518 mol\%), Xanthomonas campestris pv. campestris DSM $3586^{\mathrm{T}}(65.069 \mathrm{~mol} \%)$ and Streptomyces violaceoruber DSM 40783 (72.119 mol\%). The DNA G+C content was calculated from the ratio of deoxyguanosine $(\mathrm{dG})$ to thymidine (dT) according to the method of Mesbah et al. (1989). The DNA G+C content of strain $\mathrm{CafT}^{\mathrm{T}} 13^{\mathrm{T}}$ was $69.0 \pm 0.17 \mathrm{~mol} \%$ (mean $\pm \mathrm{SD}$ of 2 determinations).

DNA-DNA hybridization experiments with strain CafT $13^{\mathrm{T}}$ and F. australicus DSM $17894^{\mathrm{T}}$ (Zhang et al., 2007; Greene et al., 2009) were carried out as described by De Ley et al. (1970) considering the modifications described by Huß et al., (1983) by using a model Cary 100 Bio UV/VISspectrophotometer equipped with a Peltier-thermostatted $6 \times 6$ multicell changer and a temperature controller with in situ temperature probe (Varian). Hybridization was performed twice in $2 \times \mathrm{SSC}$ at $69{ }^{\circ} \mathrm{C}$ and with $10 \%$ formamide. The level of DNA-DNA relatedness between strain CafT13 ${ }^{\mathrm{T}}$ and Frondihabitans australicus DSM $17894^{\mathrm{T}}$ was $35.20 \pm 5.23 \%$ (mean \pm SD).

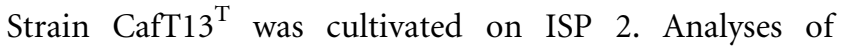
respiratory quinones and polar lipids were carried out by the Identification Service of the DSMZ (Braunschweig, Germany). The major menaquinones were MK-8 (67\%) and MK-7 (33\%). Analysis of the polar lipids revealed the presence of diphosphatidylglycerol, phosphatidylglycerol, three unidentified phospholipids, three unidentified glycolipids and one unidentified aminolipid. This polar lipid profile does not match those of any of the close relatives of strain $\mathrm{CafT} 13^{\mathrm{T}}$ and, in particular, the aminolipids were not found in any related genera of Microbacteriaceae (Table 1).

The major cellular fatty acids of strain CafT $13^{\mathrm{T}}$ were $\mathrm{C}_{18: 1}$ (79.3\%), $\mathrm{C}_{14: 0} 2-\mathrm{OH}(7.22 \%), \mathrm{C}_{17: 1} \omega 9 c(3.20 \%), \mathrm{C}_{16: 0}$ $(2.70 \%)$ and anteiso- $\mathrm{C}_{15: 0}(2.40 \%)$.

The total hydrolysate $\left(4 \mathrm{M} \mathrm{HCl}, 100{ }^{\circ} \mathrm{C}, 16 \mathrm{~h}\right)$ of the peptidoglycan of strain $\mathrm{CafT}_{13}{ }^{\mathrm{T}}$ contained ornithine, alanine, glycine, homoserine and glutamic acid in an approximate molar ratio of $1.0: 0.5: 1.0: 0.5: 1.0$. Their presence was confirmed by GC/MS ( 320 Singlequad; Varian) performed according to MacKenzie (1984). Hydroxyglutamic acid could not be detected. The partial hydrolysate $\left(4 \mathrm{M} \mathrm{HCl}, 100{ }^{\circ} \mathrm{C}, 0.75 \mathrm{~h}\right)$ contained the peptides Gly-L-Glu and D-Orn-D-Ala. These data indicated that strain $\mathrm{CafT} 13^{\mathrm{T}}$ has a peptidoglycan of type B2 $\beta\{\mathrm{Gly}\}$ [L-Hsr] D-Glu-D-Orn (Schleifer \& Kandler, 1972).

The molecular, chemotaxonomic and physiological data presented thus indicate that strain $\mathrm{CafT} 13^{\mathrm{T}}$ represents a novel species of the genus Frondihabitans, for which the name Frondihabitans cladoniiphilus sp. nov. is proposed.

\section{Emended description of the genus Frondihabitans}

The genus description follows Zhang et al. (2007), Greene et al. (2009) and the present work. Cells are aerobic, Grampositive, non-endospore-forming, irregular-shaped rods. No mycelium is produced. A range of carbohydrates and organic compounds are metabolized. 16S rRNA gene sequence analysis indicates that the genus is a member of the family Microbacteriaceae. The cell-wall peptidoglycan type is $\mathrm{B} 2 \beta$, the major cellular fatty acids are $\mathrm{C}_{18: 1}$, anteiso$\mathrm{C}_{15: 0}$ and $\mathrm{C}_{14: 0}$ 2-OH, and menaquinones MK-7, MK-8 and MK-9 are present. The polar lipid profile contains unknown aminolipids, glycolipids, phospholipids, diphosphatidylglycerol and phosphatidylglycerol.

\section{Description of Frondihabitans cladoniiphilus sp. nov.}

Frondihabitans cladoniiphilus (cla.do.ni.i.phi'lus. N.L. fem. n. Cladonia referring to the host organism and isolation source; N.L. masc. adj. philus from Gr. masc. adj. philos loving; N.L. masc. adj. cladoniiphilus Cladonia-loving).

Cells are non-motile, non-spore-forming, aerobic, irregular, short rods $(1.2-2.0 \mu \mathrm{m})$ that stain Gram-positive. Growth occurs at $1-30{ }^{\circ} \mathrm{C}$ (optimum, $22-26{ }^{\circ} \mathrm{C}$ ) and at $\mathrm{pH} 3-8$ (optimum, pH 3.7-5.4). Catalase-positive and oxidasenegative. The type $\mathrm{B} 2 \beta$ peptidoglycan contains the amino acids ornithine, alanine, glycine, homoserine and glutamic acid in an approximate molar ratio of $1.0: 0.5: 1.0: 0.5: 1.0$. Ornithine is the diagnostic diamino acid. Hydroxyglutamic acid is absent. The major cellular fatty acids are $\mathrm{C}_{18: 1}, \mathrm{C}_{14: 0}$ 2-OH, $\mathrm{C}_{17: 1} \omega 9 c, \mathrm{C}_{16: 0}$ and anteiso- $\mathrm{C}_{15: 0}$; the major menaquinones are MK-8 and MK-7. Other physiological and biochemical properties are given in Table 1. The polar lipid profile comprises diphosphatidylglycerol, phosphatidylglycerol, three unidentified phospholipids, three unidentified glycolipids and one unidentified aminolipid.

The type strain is CafT $13^{\mathrm{T}}\left(=\mathrm{DSM} 23273^{\mathrm{T}}=\mathrm{LMG} 25550^{\mathrm{T}}\right)$, isolated from the thallus of the reindeer lichen Cladonia arbuscula (Wallr.) Rabenh. sampled from the understorey of a natural alpine spruce forest in the region of Styria, Austria. The mean DNA G $+\mathrm{C}$ content of the type strain is $69.0 \pm 0.17 \mathrm{~mol} \%$.

\section{Acknowledgements}

We thank Christian Berg (Graz) for nomenclatural advice and Claudia Draskowitsch for technical assistance. This research was funded by a grant from the Austrian Science Foundation (FWF project E-1653P19098).

\section{References}

Bates, S. T., Cropsey, G. W. G., Caporaso, J. G., Knight, R. \& Fierer, N. (2011). Bacterial communities associated with the lichen symbiosis. Appl Environ Microbiol 77, 1309-1314. 
Bjelland, T., Grube, M., Hoem, S., Jorgensen, S. L., Daae, F. L., Thorseth, I. H. \& Øvreås, L. (2011). Microbial metacommunities in the lichen-rock habitat. Environ Microbiol Rep 3, 434-442.

Bright, M. \& Bulgheresi, S. (2010). A complex journey: transmission of microbial symbionts. Nat Rev Microbiol 8, 218-230.

Cardinale, M., Vieira de Castro, J., Jr, Müller, H., Berg, G. \& Grube, M. (2008). In situ analysis of the bacterial community associated with the reindeer lichen Cladonia arbuscula reveals predominance of Alphaproteobacteria. FEMS Microbiol Ecol 66, 63-71.

Cashion, P., Holder-Franklin, M. A., McCully, J. \& Franklin, M. (1977). A rapid method for the base ratio determination of bacterial DNA. Anal Biochem 81, 461-466.

De Ley, J., Cattoir, H. \& Reynaerts, A. (1970). The quantitative measurement of DNA hybridization from renaturation rates. Eur $J$ Biochem 12, 133-142.

Eck, R. V. \& Dayhoff, M. O. (1966). Atlas of Protein Sequence and Structure. Silver Springs, MD: National Biomedical Research Foundation.

Felsenstein, J. (1989). PHYLIP - phylogeny inference package (version 3.2). Cladistics 5, 164-166.

Felsenstein, J. (2005). PHYLIP (Phylogeny Inference Package) version 3.6. Distributed by the author. Department of Genome Sciences, University of Washington, Seattle.

Greene, A. C., Euzéby, J. P., Tindall, B. J. \& Patel, B. K. C. (2009). Proposal of Frondihabitans gen. nov. to replace the illegitimate genus name Frondicola Zhang et al. 2007. Int J Syst Evol Microbiol 59, 447448.

Grube, M. \& Berg, G. (2009). Microbial consortia of bacteria and fungi with focus on the lichen symbiosis. Fungal Biol Rev 23, 72-85.

Grube, M., Cardinale, M., de Castro, J. V., Jr, Müller, H. \& Berg, G. (2009). Species-specific structural and functional diversity of bacterial communities in lichen symbioses. ISME J 3, 1105-1115.

Hodkinson, B. P. \& Lutzoni, F. (2009). A microbiotic survey of lichenassociated bacteria reveals a new lineage from the Rhizobiales. Symbiosis 49, 163-180.

Huß, V. A. R., Festl, H. \& Schleifer, K. H. (1983). Studies on the spectrophotometric determination of DNA hybridization from renaturation rates. Syst Appl Microbiol 4, 184-192.

Jukes, T. H. \& Cantor, C. R. (1969). Evolution of protein molecules. In Mammalian Protein Metabolism, vol. 3, pp. 21-132. Edited by $\mathrm{H}$. N. Munro. New York: Academic Press.

Kidd, K. K. \& Sgaramella-Zonta, L. A. (1971). Phylogenetic analysis: concepts and methods. Am J Hum Genet 23, 235-252.

Kluge \& Farris, J. S. (1969). Quantitative phyletics and the evolution of anurans. Syst Zool 18, 1-32.

Larkin, M. A., Blackshields, G., Brown, N. P., Chenna, R., McGettigan, P. A., McWilliam, H., Valentin, F., Wallace, I. M., Wilm, A. \& other authors (2007). Clustal W and Clustal X version 2.0. Bioinformatics 23, 2947-2948.

Lee, S. D. (2010). Frondihabitans peucedani sp. nov., an actinobacterium isolated from rhizosphere soil, and emended description of the genus Frondihabitans Greene et al. 2009. Int J Syst Evol Microbiol 60, 1740-1744.

MacKenzie, S. L. (1984). Amino acids and peptides. In Gas Chromatography/Mass Spectrometry Applications in Microbiology, pp. 157-204. Edited by G. Odham, L. Larsson \& P. Mardh. New York: Plenum.

Mesbah, M., Premachandran, U. \& Whitman, W. B. (1989). Precise measurement of the $\mathrm{G}+\mathrm{C}$ content of deoxyribonucleic acid by highperformance liquid chromatography. Int J Syst Bacteriol 39, 159-167.

Miller, J. A., Kalyuzhnaya, M. G., Noyes, E., Lara, J. C., Lidstrom, M. E. \& Chistoserdova, L. (2005). Labrys methylaminiphilus sp. nov., a novel facultatively methylotrophic bacterium from a freshwater lake sediment. Int J Syst Evol Microbiol 55, 1247-1253.

Rzhetsky, A. \& Nei, M. (1993). Theoretical foundation of the minimum-evolution method of phylogenetic inference. Mol Biol Evol 10, 1073-1095.

Saitou, N. \& Nei, M. (1987). The neighbor-joining method: a new method for reconstructing phylogenetic trees. Mol Biol Evol 4, 406425.

Schleifer, K. H. \& Kandler, O. (1972). Peptidoglycan types of bacterial cell walls and their taxonomic implications. Bacteriol Rev 36, 407-477.

Schneider, T., Schmid, E., de Castro, J. V., Jr, Cardinale, M., Eberl, L., Grube, M., Berg, G. \& Riedel, K. (2011). Structure and function of the symbiosis partners of the lung lichen (Lobaria pulmonaria L. Hoffm.) analyzed by metaproteomics. Proteomics 11, 2752-2756.

Schumann, P., Kämpfer, P., Busse, H. J., Evtushenko, L. I. \& Subcommittee on the Taxonomy of the Suborder Micrococcineae of the International Committee on Systematics of Prokaryotes (2009). Proposed minimal standards for describing new genera and species of the suborder Micrococcineae. Int J Syst Evol Microbiol 59, 1823-1849.

Selbmann, L., Zucconi, L., Ruisi, S., Grube, M., Cardinale, M. \& Onofri, S. (2010). Culturable bacteria associated with Antarctic lichens: affiliation and psychrotolerance. Polar Biol 33, 71-83.

Shirling, E. B. \& Gottlieb, D. (1966). Methods for characterization of Streptomyces species. Int J Syst Bacteriol 16, 313-340.

Tamaoka, J. \& Komagata, K. (1984). Determination of DNA base composition by reversed-phase high-performance liquid chromatography. FEMS Microbiol Lett 25, 125-128.

Tamura, K., Dudley, J., Nei, M. \& Kumar, S. (2007). MEGA4: molecular evolutionary genetics analysis (MEGA) software version 4.0. Mol Biol Evol 24, 1596-1599.

Tindall, B. J., Kämpfer, P., Euzéby, J. P. \& Oren, A. (2006). Valid publication of names of prokaryotes according to the rules of nomenclature: past history and current practice. Int J Syst Evol Microbiol 56, 2715-2720.

Tittsler, R. P. \& Sandholzer, L. A. (1936). The use of semi-solid agar for the detection of bacterial motility. J Bacteriol 31, 575-580.

Zhang, L., Xu, Z. \& Patel, B. K. C. (2007). Frondicola australicus gen. nov., sp. nov., isolated from decaying leaf litter from a pine forest. Int J Syst Evol Microbiol 57, 1177-1182. 